\title{
WORK TRENDS IN NEW ZEALAND
}

\author{
Vasantha Krishnan, Andrew Hunter and Kay Goodger \\ Department of Statistics
}

This paper presents some of the main findings from the Department of Statistics forthcoming publication New Zealand Social Trends - Work. This is the third report in the Social Trends series, the previous publications having focussed on Education and Income. The report identifies and describes major trends in work and the workforce in New Zealand during the post-war period. It is principally concerned with trends in aspects of the supply of labour.

The first part of the report focusses on the changing nature of work. It describes structural changes in paid work, changes in the geographic distribution of paid work, the decrease in the average working week, the emergence of a diversity of work arrangements, the growth in selfemployment and small businesses and recognition of unpaid work.

The second part of the report is concerned with the workforce. It begins by outlining changes in the size and growth of the labour force, and factors determining growth over the last 40 years. Major trends and issues that have shaped the contemporary workforce are then discussed, with special attention being given to the increasing participation of women in paid employment, gender and ethnic differentials and patterns in employment, the ageing of the workforce, labour force mobility, the education and skill levels of the labour force, income differentials and unemployment.

In this presentation we have confined ourselves to outlining major trends in employment, labour force participation and unemployment. Particular attention is paid to the outcomes of the structural change and economic conditions which have progressively transformed New Zealand's paid working environment since the mid 1980s. ${ }^{1}$

\section{Employment}

\section{Labour Force Contraction}

Support for the assertion that the New Zealand labour market has been transformed by the structural and economic changes of the mid-to late 1980 s is not difficult to uncover. Labour force growth during the post-war period has consistently mirrored trends in the size of the working age population. This pattern was fractured in the late 1980 s by the joint impact of economic restructuring and recession. For the first time in the post-war period, the labour force contracted during an intercensal period while the working age population continued to expand (see Figure 1).

The contraction of the labour force is associated with a fall in employment between 1986 and 1991.2 The pattern of steady, if unspectacular growth which has typified employment trends in the post-war years has been replaced by employment contraction during the most recent intercensal period. Between 1986 and $1991 \mathrm{Neu} Z \mathrm{Zcal}$ and recorded a net decline in employment of 111.500 persons.

The majority of this decline occurred in the manufacturing sector, which recorded a net loss 102.400 employed persons. Primary sector employment also fell. The service sector was the only group to achieve a small increase in employment levels during this period.

Figure 1. Female labour force participation rate by age group 1981-1991

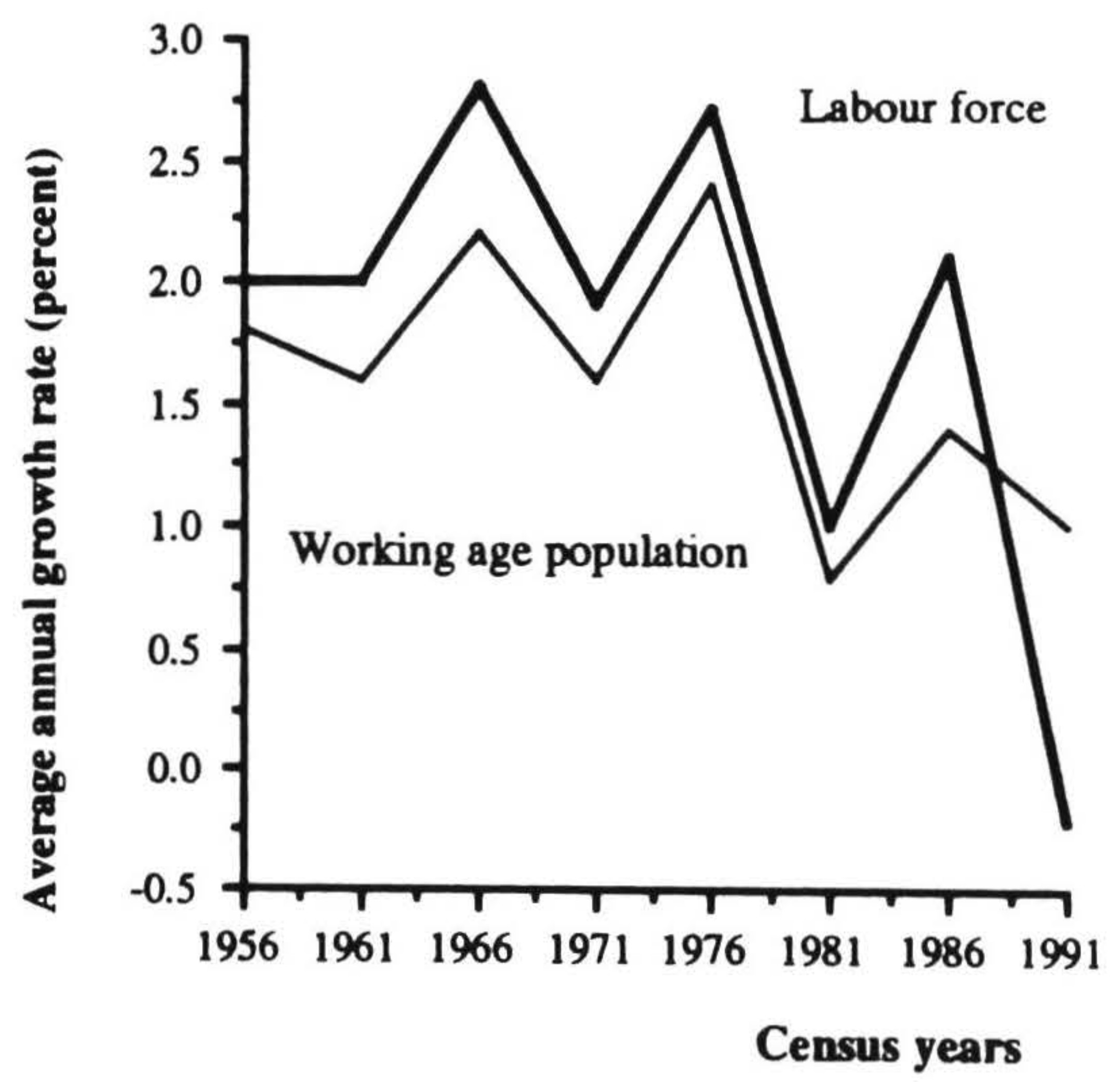

Source: NZ Census of Population \& Dwellings

Note: Labour force defined here as persons aged 15-64 years employed for 20 hours or more per week or unemployed and seeking work. 


\section{Labour Force Participation}

\section{Women's Labour Force Participation Stalls}

The impact of this most recent period of negative employment growth is reflected in the divergence of labour force participation rates of a number of groups from their historical paths. ${ }^{3}$ The most established of these trends had been the steadily increasing involvement of women in paid employment.

The rate at which women participated in the labour force rose from 25.0 percent in 1951 to 45.2 percent in 1986, an increase of 81 percent. Recently, however, this historic rise in female labour force participation has stalled. In fact, for the first time since the 1950s the Population Census recorded a slight drop in the proportion of females in the labour force, from $\mathbf{4 5 . 2}$ percent in 1986 to 44.7 percent in 1991 (see Figure 2).

Figure 2. Female labour force participation rate 1951-1991

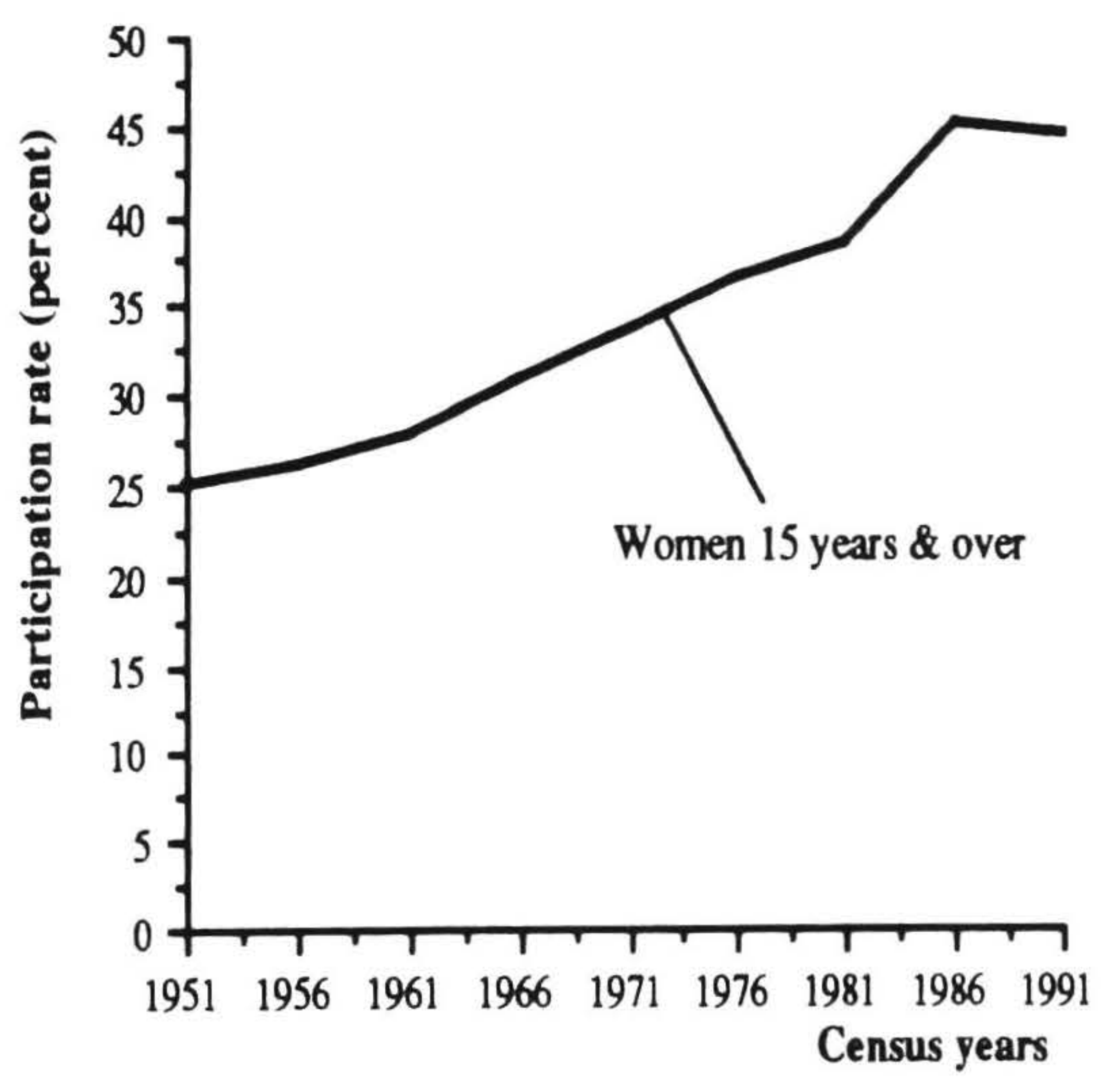

Most of this decline has occurred among younger women and is a consequence of limited job opportunities for new entrants to the paid workforce and higher educational participation. For women under 20, labour force participation rose from 49.3 percent in 1981 to 53.2 percent in 1986, then dropped sharply to 40.7 percent in 1991 (see Figure 3).

Similarly, the participation of women aged 20-24 increased from 62.9 percent in 1981 to a peak of 70.3 percent in 1986, but fell back to 67.2 percent in 1991 .

In contrast, women aged 25-29 and 40-59 years have continued to increase their participation in the labour force. It should be noted, however, that the increases recorded by these age groups were much smaller between
1986 and 1991 (averaging three percentage points) than they were in the previous intercensal period, when they increased by an average of eight percentage points. Participation by women in their thirties stalled between 1986 and 1991.

\section{Figure 3. Female labour force participation rate by age group 1981-1991}

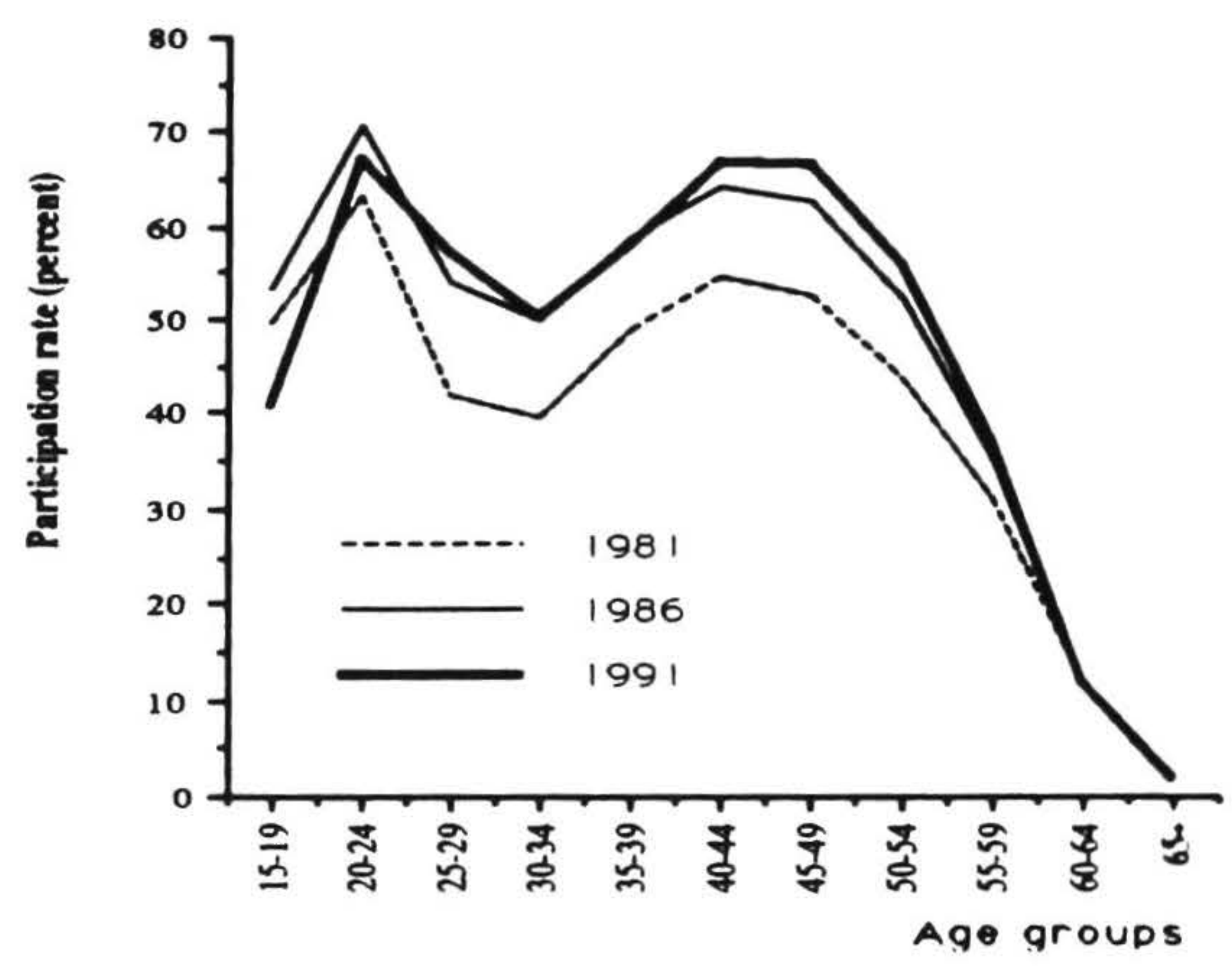

Decline in Men's Participation Accelerates

The changes of the late 1980s have accelerated the trend towards gradually declining labour force participation among men in the entry (15-24 years) and exit (55-64 years) age groups (see Figure 4).

Figure 4. Male labour force participation rate by age group 1951-1991

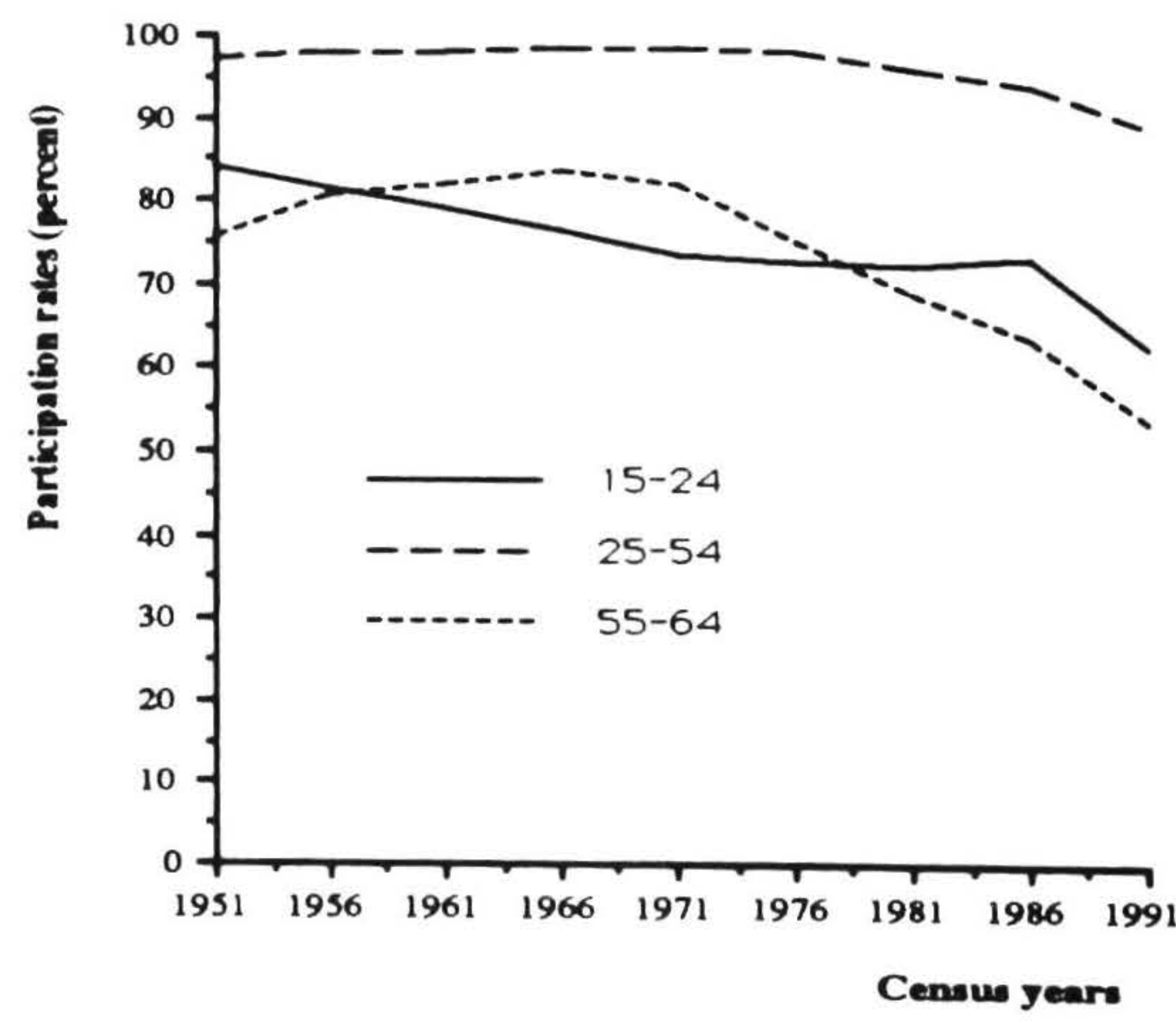

The decline has been strongest among young men aged 15-19 years. Many men aged 15-19 years, faced with reduced employment opportunities, have delayed entering or withdrawn from the labour force. Labour force participation for this group fell from 58.7 percent in 1986 to 44.3 percent in 1991 . This trend is reflected in the 
increased numbers and proportions remaining in schools or entering tertiary institutions. In the five years between 1986 and 1991 , the participation of $15-19$ year olds in post - compulsory education increased from 53 percent to 66 percent.

Participation amongst older men in the 55-64 year age group has followed a different path. It increased steadily from $\mathbf{7 5 . 4}$ percent in $\mathbf{1 9 5 1}$ to a peak of $\mathbf{8 3 . 4}$ percent in 1966. A trend towards earlier retirement was already evident by 1976 . However, after the age of eligibility for universal retirement income was reduced to 60 years in early 1977 , participation rates for this age group showed a steady decline. More recently, reduced prospects for reemployment amongst unemployed older men may have caused some todrop out of the labour force before retirement age. Between 1986 and 1991, the participation rate of men age 55-59 years fell from 84.7 to 74.9 percent.

Men aged 25-54 years continue to have the highest participation rates, with at least 97 percent employed or seeking work in the 30 years to 1981 . However, in the last five years, the effect of decreasing job opportunities can also be observed in this age group. By 1991, labour force participation had declined to a post-war low of $\mathbf{8 8 . 6}$ percent.

\section{Marked Decline in Participation of Maori Men}

For the thirty years to 1986 , the labour force participation rate of Maorimales was higher than that for males generally. This reflects the younger age structure of the Maori population and a tendency to enter the labour force at an early age. Since the mid-1980s, there has been a marked decline in the labour force participation of Maori men. In 1986, four out of five Maori men (79.8 percent) were in the labour force; by 1991, this figure had fallen to two in every three (66.7 percent) (see Figure 5).

Figure 5. Male and female Maori labour force participation rates, 15 years and over

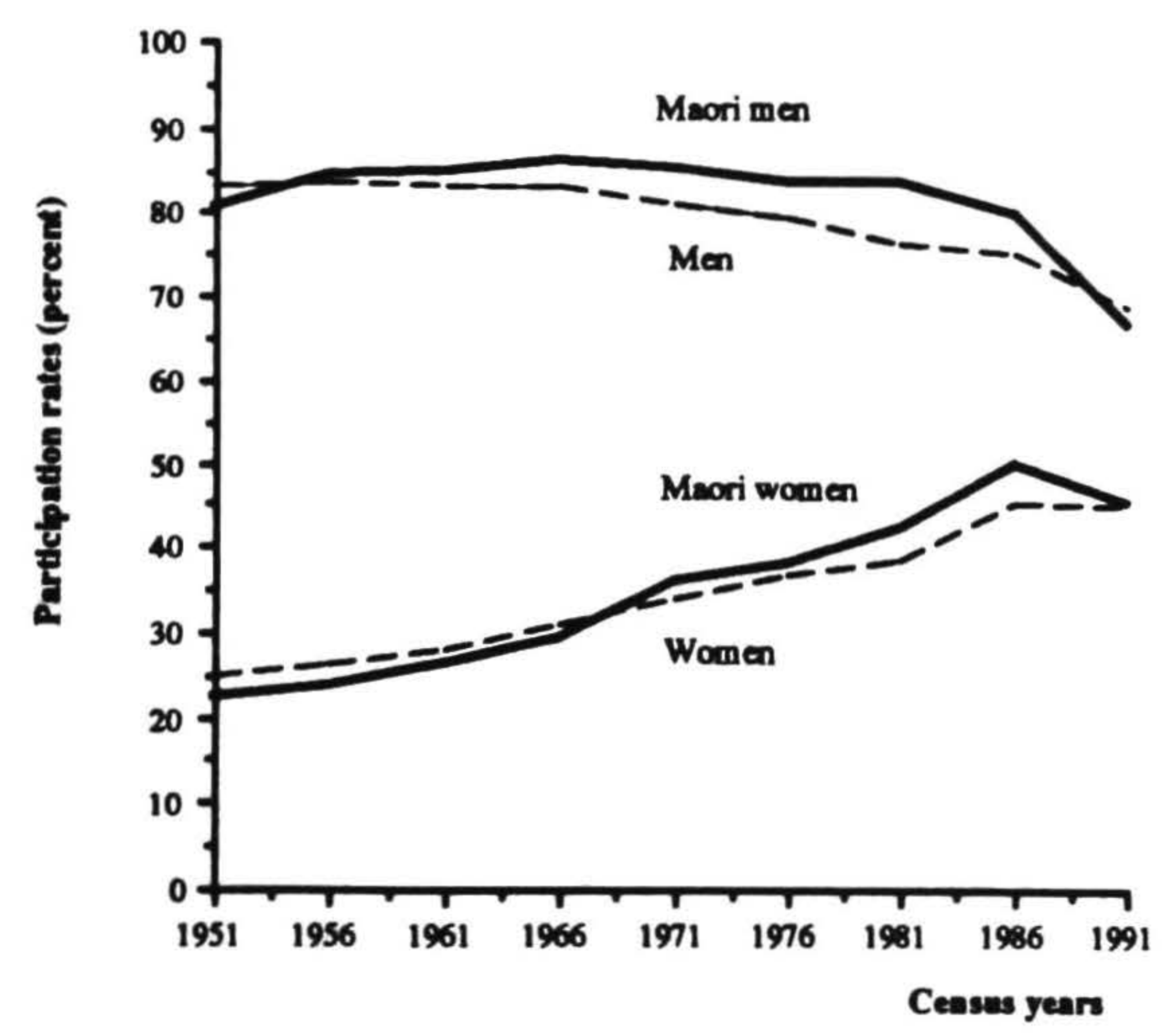

As for males in general, the largest declines in participation have occurred amongst young Maori males and those in their late fifties. For those aged 15-19, labour force participation fell from around 65 percent in 1981 and 1986, to 44.8 percent in 1991 , a drop of some 20 percentage points in 5 years. In 1981, 95.6 percent of Maori men aged 20-24 were in the labour force. Five years later, this proportion was down to 89.6 percent and by 1991 it had fallen to 75.6 percent. A similar large drop in participation was recorded for Maori males aged 55-59 years, from 75.6 percent in the labour force in 1986, to 60.0 percent in 1991 (see Figure 6).

\section{Figure 6. Male and female Maori labour force participation rates by age group 1981- 1991}

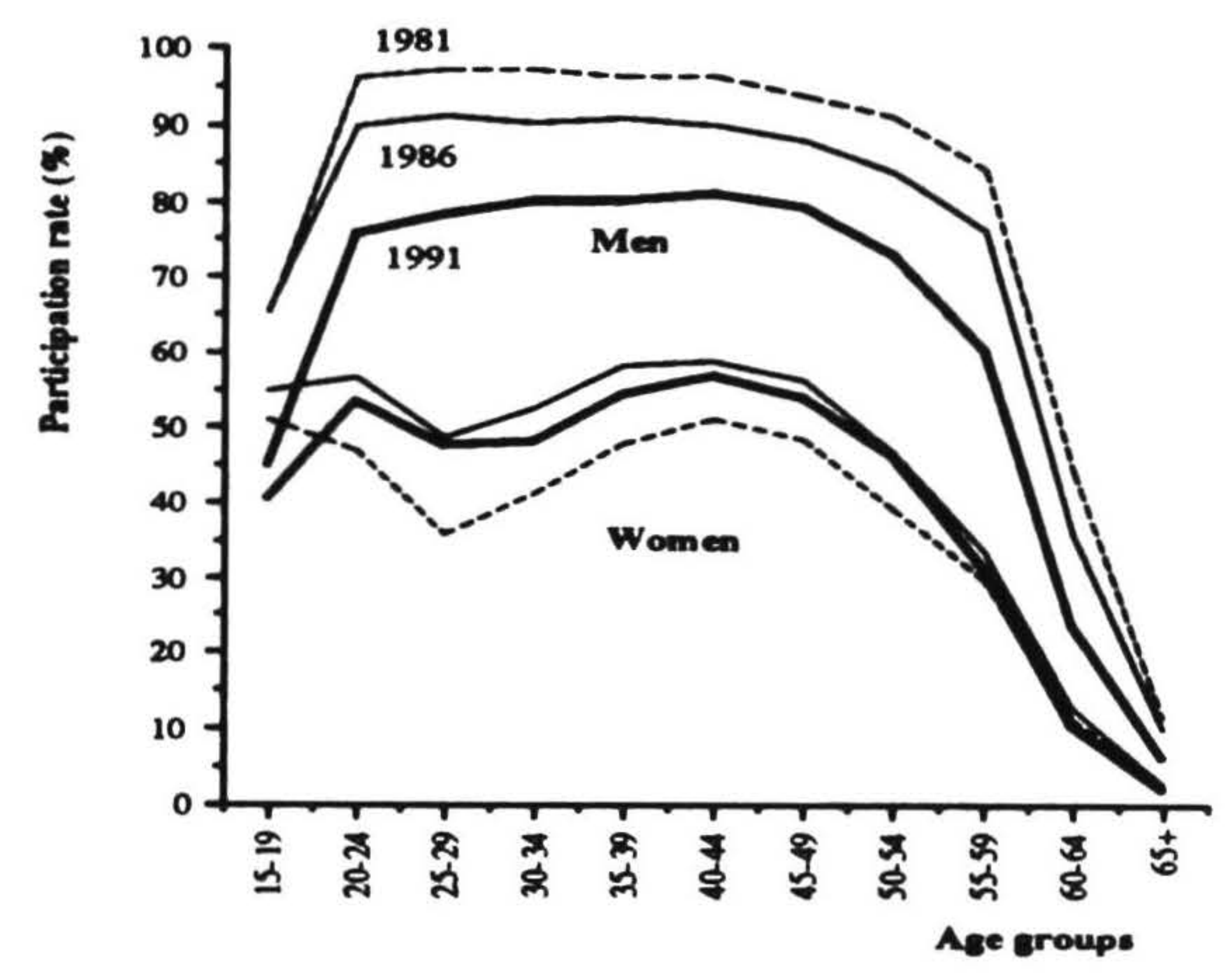

In contrast, Maori women increased their participation in the first half of the $1980 \mathrm{~s}$, from an overall rate of 42.2 percent in 1981 to 49.9 percent in 1986. Maori women between the ages of 20-39 recorded an average increase of more than 10 percentage points in the five years to 1986 . By 1991 however, participation across all ages had dropped back to 45.1 percent. For those under 20 years, labour force participation was well down, from 54.7 percent in 1986 to 40.3 percent in 1991.

\section{Sharpest Decline in Participation Amongst Pacific Island Polynesians}

The most dramatic decline in labour force participation in the 1980s has occurred in the Pacific Island Polynesian population, which began the decade with much higher than average overall workforce participation rates.

In 1981, 85.9 percent of Pacific Island Polynesian men were in the labour force; by 1991 , the proportion had fallen to 64.5 percent, the lowest rate for men in the three main ethnic groups. Again, the decline has been greatest for youth. Amongst young Pacific Island Polynesians under 20 years of age, participation rates fell by about a third between 1986 and 1991, from 54.8 to 34.2 percent for 
males and from 48.0 to 33.5 percent for females (see Figure 7).

Pacific Island Polynesian women had a higher overall participation rate in 1981 (48.4 percent) than either Maori women (42.2 percent) or women in the population as a whole (38.6 percent). In 1986, their participation rate had increased to 54.3 percent and was still the highest amongst women in the three main ethnic groups. By 1991, however, the participation rates of Pacific Island Polynesian women had declined to 45.6 percent converging with those of Maori and other women.

Figure 7. Male and female Pacific Island Polynesian labour force participation rates, 19811991

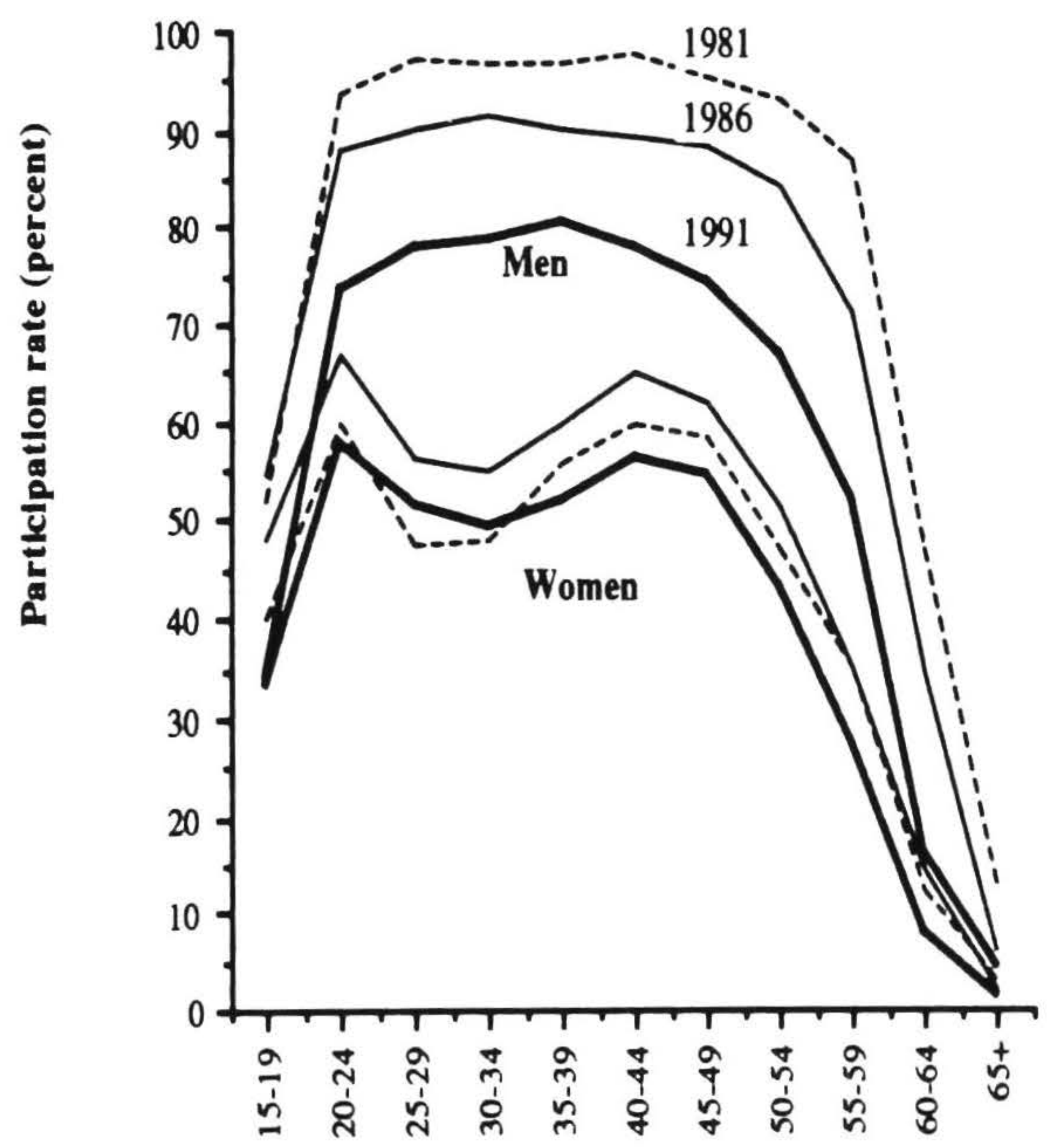

Age group

both males and females in the Pacific Island Polynesian population, the 1991 Population Census showed a substantial decline in labour force participation across all age groups.

\section{Unemployment (4)}

While the "true" level of unemployment remains a contentious issue (5), the predominant trend in unemployment is irrefutable (see Figure 8).

The emergence of large scale unemployment has been a phenomenon of the 1980s which has continued unabated into the early years of this decade. It is now well documented that unemployment is borne unequally within New Zealand society. Unemployment rates for youth, Maori, and increasingly, Pacific Island minorities are two to three times the national average, and rising.

Figure 8. Number unemployed 1955-1992

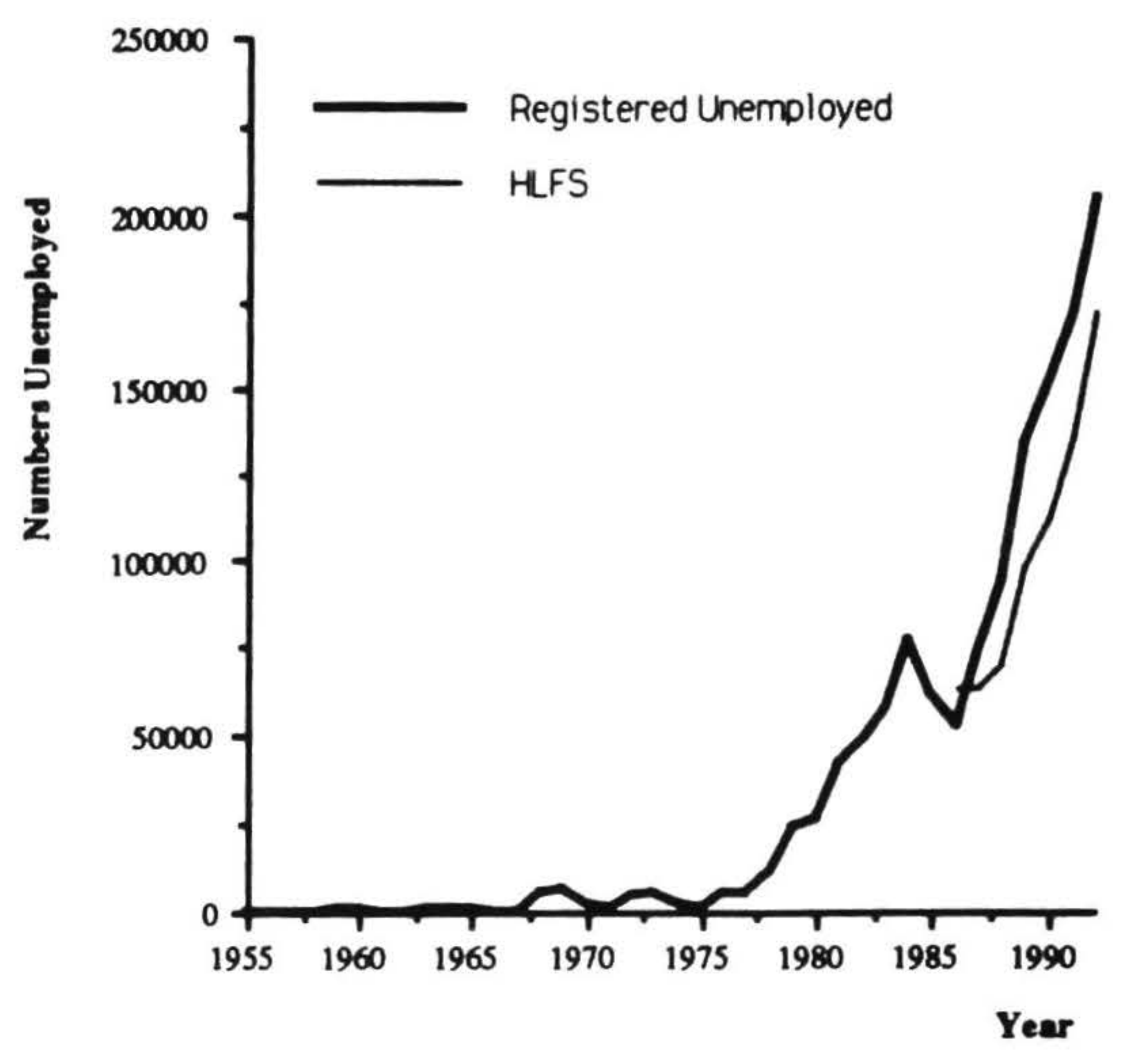

Unemployment Concentrated Amongst Youth, Maori, Pacific Island Polynesians

In the 1992 March quarter of the Household Labour Force Survey, individuals aged $15-24$ years comprised 23 percent of the labour force but 42 percent of the unemployed. The unemployment rate for 15-19 year olds was 22 percent, with the rate for 20-24 year olds slightly lower at 19 percent (see Figure 9).

\section{Figure 9. Unemployment rates by age group 1992 March quarters}

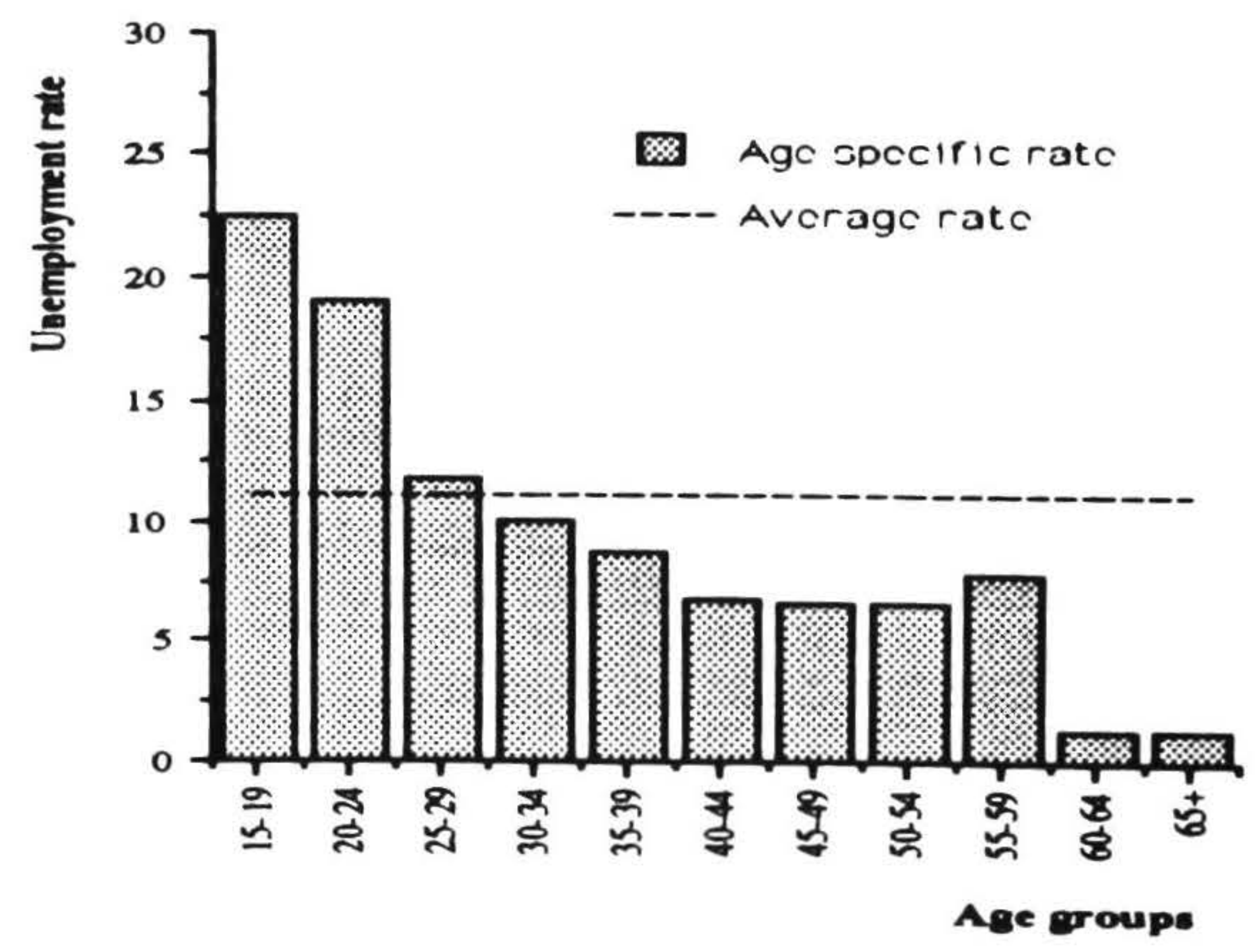

While the concentration of unemployment in youth age groups remains marked, it has fallen substantially since the March 1988 quarter when youth accounted for 51 percent of total unemployment. This decline is attributable to the increased participation of young people in post-compulsory 
education and large increases in unemployment for people over 25 years of age.

\section{Ethnic Disparities}

High rates of Maori unemployment have been a consistent feature of the New Zealand labour market for at least three decades. In the March 1992 quarter, Maori comprised 22 percent of the total unemployed, despite representing only 9 percent of the labour force. The Maori unemployment rate now stands at 27 percent, three times the equivalent rate for European/Pakeha (see Table 1).

The significance of these disparities is magnified when they are viewed against a background of high youth unemployment. An examination of ethnic unemployment by age reveals rates estimated to be approaching, or in excess of 50 percent.

\section{Table 1 Unemployment by Ethnic Group March Quarter 1992}

\section{European NZ Maori PIP Other Total /Pakeha}

Unemployment

$\%$ of Total

$\begin{array}{llllll}\text { Unemployment } & 64 & 22 & 10 & 5 & 100\end{array}$

$\%$ of Total

Labour Force

Source: Household Labour Force Survey, Department of Statistics.

While the Maori unemployment rate has been at comparatively high levels for some decades, it has recently been exceeded by a sharp rise in Pacific Island Polynesian unemployment. Unemployment rates for Pacific Island Polynesian workers increased from 6 percent in the March 1987 quarter to 32 percent in the March 1992 quarter. Pacific Islanders now account for 10 percent of total unemployment while comprising only 3 percent of the labour force.

This sharp rise has been the result of inverse trends in employment opportunities and numbers in the labour force for Pacific Island workers. Between the March 1987 and 1992 quarters, Pacific Island employment fell by 20 percent. The majority of this decline was in manufacturing industries. In the March 1987 quarter, 23,500 Pacific Island workers were employed in manufacturing (50 percent of all Pacific Island employment); by the 1992 March quarter this figure had fallen to 13,900 (37 percent of Pacific Island employment). This decline was compounded by a 11 percent increase in the size of the Pacific Island labour force, up from 49,600 to 55,000 persons. In combination, these changes account for much of the fivefold increase in Pacific Island Polynesian unemployment rates since 1987.

\section{Increased Duration of Unemployment}

As the number of people without paid employment has continued to increase, so too has the proportion of people being locked into long-term unemployment. For the year ended March 1992,47 percent of unemployed workers had been without work for 27 weeks or more. A further 18 percent were classified as medium-term unemployed (1426 weeks), while 35 percent fell within the short-term category (1-13 weeks).

Trends in the proportion of unemployed peoplc in these categories must be treated with some caution, as a change in numbers in a given category can produce apparently contradictory changes in other categories. For example. a surge in unemployment will initially lead to a doclinc in the proportion of medium and long-term unemployed without any changes in their number having occurred. Should unemployment then stabilize, the proportion of medium and long-term unemployed will steadily increase. despite stability in the total number without work.

While this qualification must be noted, the rate of increase between 1987 and 1992 has been sufficiently stable for a consistent trend in duration of unemployment to emerge (see Figure 10).

\section{Figure 10 The distribution of the unemployed by duration, 1987-1992}

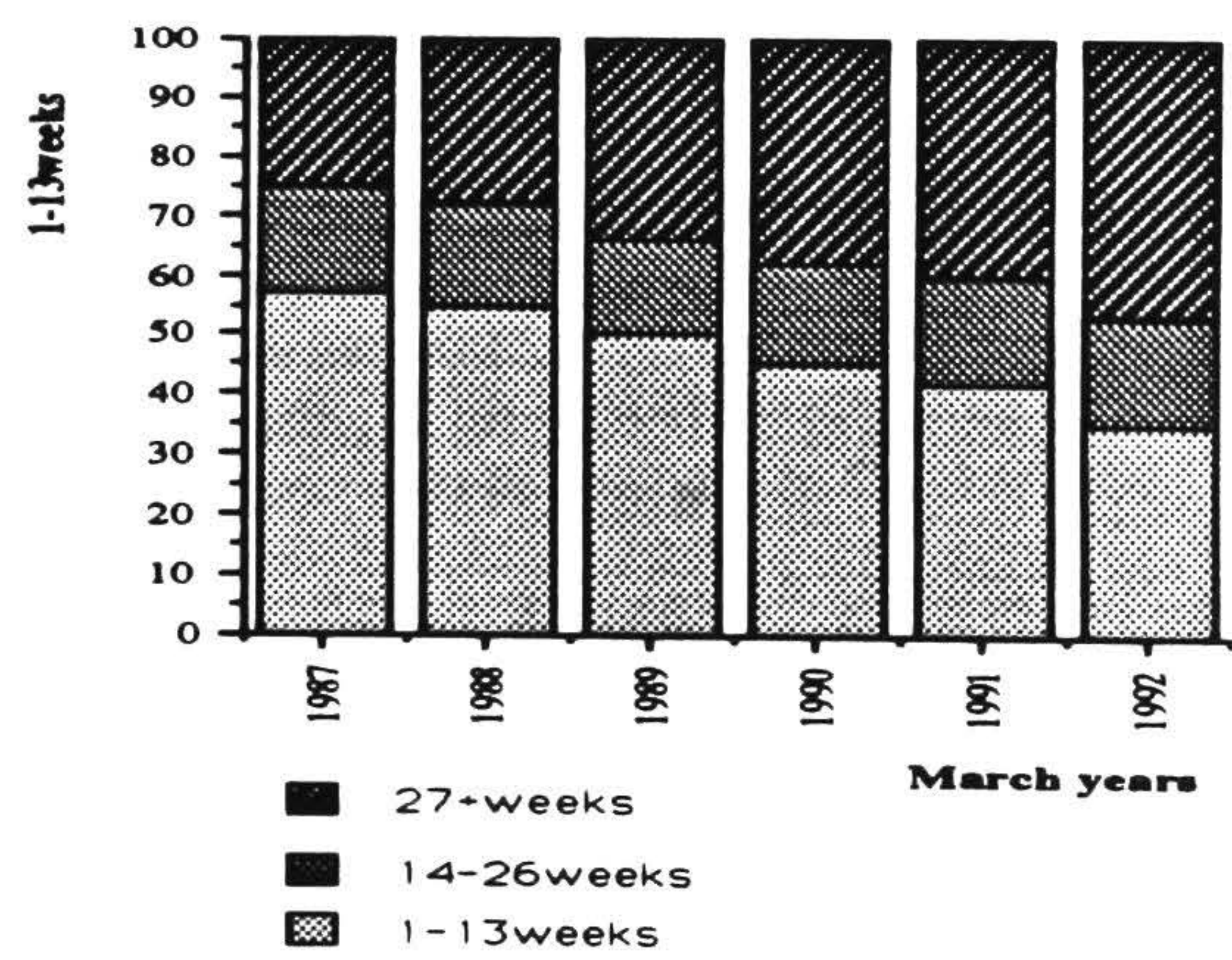

Over the past five years, the numbers of the long-term unemployed have increased sixfold, from 12,200 in 1987 to 75,500 in 1992 , compared with a less than threefold increase in total unemployment. In 1987, the long-term unemployed represented 25 percent of the total unemployed; by 1992 this proportion had increased to 47 percent. Medium-term unemployment remained relatively stable as a proportion of the total unemployed, while shortterm unemployment fell from 57 to 35 percent. 
In the March 1987 quarter, an estimated 6,000 people ( 9 percent of the unemployed) had been without work for 12 months or more. By March 1992, the figure had increased to 46,900 individuals, 27 percent of those officially unemployed. Of this total, 26,400 had been unemployed for between one and two years. The remaining 20,500 (12 percent of the total unemployed) had been without work for more than two years.

About two thirds ( 68 percent) of those who had been unemployed for 12 months or more were male. Maori and Pacific Island Polynesians were substantially overrepresented in this group in comparison with their labour force presence. In 1992, Maori comprised 30 percent of those unemployed for 12 months or more compared to 9 percent of the labour force, while Pacific Island Polynesians comprised a further 15 percent compared to 3 percent of the labour force.
While these figures may appear extreme, it must be emphasised they form a minimum estimate of the level of unemployment. The official definition of unemployment in New Zealand is based on the International Labour Organisation (ILO) guidelines, to allow for the highest possible level of international comparability. In recognition that the requirements of this definition are restrictive, the department provides a range of alternative measures to meet the needs of different groups of users. The most comprehensive of these is the "jobless".

\section{Profiling the Jobless}

The jobless is a measure of unemployment which includes all people without a paid job who are wanting paid work (6). The preceding discussion has focussed almost exclusively on trends and characteristics of persons who are "strongly attached" to the labour force. This group, the official unemployed, comprised 68 percent of the total

Table 2 Labour Market Attachment Level of the Working-Age Population Without Jobs March 1992 Quarter

$\begin{array}{lllll}\begin{array}{l}\text { Official Classification } \\ \text { of labour force status }\end{array} & \begin{array}{l}\text { Labour market } \\ \text { attachment } \\ \text { level }\end{array} & \begin{array}{l}\text { Job-seeking } \\ \text { status }\end{array} & \begin{array}{l}\text { Availability } \\ \text { for work }\end{array} & \begin{array}{l}\text { Number } \\ \text { Percent change } \\ \text { March 1987- } \\ \text { March 1992 }\end{array}\end{array}$

\begin{tabular}{|c|c|c|c|c|c|}
\hline \multirow[t]{6}{*}{$\begin{array}{l}\text { Not in the } \\
\text { labour force }\end{array}$} & Unattached & $\begin{array}{l}\text { Not seeking } \\
\text { work }\end{array}$ & Not available & 844,900 & +9 \\
\hline & $\begin{array}{l}\text { Marginally } \\
\text { attached }\end{array}$ & $\begin{array}{l}\text { Not actively } \\
\text { seeking work }\end{array}$ & Available & 72,600 & +92 \\
\hline & & & $\begin{array}{l}\text {-seeking } \\
\text { through } \\
\text { newspaper only }\end{array}$ & 15,400 & +170 \\
\hline & & & -discouraged & 17,100 & +148 \\
\hline & & & -other & 40,100 & +59 \\
\hline & & $\begin{array}{l}\text { Actively } \\
\text { seeking work }\end{array}$ & Not available & 11,300 & +5 \\
\hline \multirow[t]{5}{*}{ Unemployed } & $\begin{array}{l}\text { Strongly } \\
\text { attached }\end{array}$ & $\begin{array}{l}\text { Actively } \\
\text { seeking work }\end{array}$ & Available & 180,7000 & +170 \\
\hline & & \multicolumn{2}{|c|}{ Total actively seeking work } & 192,000 & +147 \\
\hline & & \multicolumn{2}{|c|}{ Total marginally attached } & 83,900 & +73 \\
\hline & Total jobless (marg & \multirow{2}{*}{\multicolumn{2}{|c|}{$\begin{array}{l}\text { tached plus strongly attached) } \\
\text { Total not in the labour force }\end{array}$}} & 264,600 & +129 \\
\hline & & & & 928,800 & +13 \\
\hline
\end{tabular}

Source: Household Labour Force Survey, Department of Statistics. 
jobless for the March quarter 1992. A further 32 percent, or 83,900 persons, identified themselves as wishing to work but did not satisfy the restrictive criteria for official unemployment. This latter group is classified as "marginally attached" to the labour force (see Table 2).

Numbers of persons marginally attached to the labour force have increased by 72 percent in the last five years. The largest sub-group in this category comprises jobless persons who were not actively seeking work but who were available should work present itself or employment conditions alter. This sub-category accounted for 87 percent $(72,600$ persons) of the marginally attached in the March quarter 1992. A further 11,300 persons (13 percent) were seeking work but were not immediately available to start due to temporary illness, inability to find suitable childcare or educational commitments.

\section{“Marginally Attached" Mainly Women.}

The majority of people marginally attached to the labour force are women. In comparison with the gender distribution of the labour force as a whole, women are substantially over-represented in this group. In the March quarter 1992. women comprised 43 percent of the total labour force but 62 percent $(52,000)$ of individuals marginally attached to the labour force. This pattern was repeated through all subgroups of the marginally attached category, i.e. seeking through newspaper, discouraged jobseekers, etc.

This gender disparity is partially offset by the male dominance among the official unemployed, where 59 percent $(106,400)$ were male and 41 percent $(74,300)$ female at the March quarter 1992. The higher representation of jobless men among the official unemployed and the over-representation of women among those marginally attached to the labour force reflects the weaker ties women have to the labour market, especially in times of economic recession.

\section{Summary and conclusions}

This paper has presented a selection of the findings on labour market trends appearing in the Department of Statistics forthcoming publication, New Zealand Social Trends - Work. This report quantifies the labour market implications of the structural and economic changes which have occurred in recent years. It places these changes in historical context, adding a sense of scale which is often missing from cross-sectional presentations. Clearly, the employment arena is passing through a period of major change which is imposing heavy burdens upon sub-groups within the community. While this paper has presented a picture of this process, it remains to be determined what the long-term implications of these trends are for New Zealand society.

\section{Conclusion}

This paper has highlighted the following main changes occurring in the New Zealand labour market since the mid1980 s, a period characterised by economic restructuring and recession. For the first time in the postwar period, the labour force contracted while the working age population continued to expand. Most of the fall in employment between 1986 and 1991 occurred in the manufacturing sector. In the late 1980s, there has been a sharp drop in the participation of young women and men. This has contributed to the stalling of women's historic rise in participation and the acceleration of a long term downward trend amongst men. Since the mid-1980s, there has been a marked decline in the labour force participation of Maori men, young Maori women and Pacific Island Polynesians. Large scale and long term unemployment has emerged, affecting youth, Maori and Pacific Island Polynesians disproportionately.

\section{Future Research}

The substantial changes that have taken place in the labour market area since the mid 1980s provide impetus for continuing research which can illustrate the current transformation of work in New Zealand. Efforts to measure these changes have highlighted a number of gaps in the available data. For example, there is a need for information on the timing of hours actually worked and the prevalence of part-year employment.

Some of the dynamics of labour market activity are not yet well measured. These include labour force mobility (flows in and out of the workforce as well as flows in and out of occupation and industry groups), women's patterns of entry/re-entry to paid work, and the relationship between paid and unpaid work.

The Department of Statistics and the Department of Labour are currently jointly involved in research on the extent to which the workforce is covered by employment contracts. Results of the second Employment Contracts Survey are expected to be available in October 1993.

\section{Notes}

1.The 1991 Population Census figures presented in this paper are based on a total count of Maori and Pacific Island Polynesian Census responses and a 10 percent sample of all others. Between the 1986 and 1991 Population Censuses the size of the labour force has been affected by definitional changes in the scope of unemployment. To maintain comparability, the 1991 labour force figures used here are based on the 1986 definition of unemployment.

2. For purposes of historical continuity, employment is defined as all persons aged 15 years and over working for pay or profit for 20 or more hours per week. 
3. Labour force participation rates are based on all persons aged 15 years and over working 20 or more hours per week or unemployed and seeking work.

4. The unemployed are defined as all persons in the working-age population who during their reference week were without a paid job, were available for work and:

a) had actively sought work in the past four weeks ending with the reference week, or

b) had a new job to start within four weeks.

5. For an outline of this debate, see Shirley, I. et al., 1990 Unemployment in New Zealand: 116-125.

6. Specifically, this definition covers the official unemployed plus those persons who were without a job and available for work, but who were not actively seeking work, plus those actively seeking work but who were not immediately available to start. 